\title{
Trace and rare earth elements (REE) distribution in Ngaye alluvial sediments of Mbere-Djerem Basin, North Cameroon: implications for origin, depositional conditions and paleoclimate reconstitution
}

\author{
FADIL-DJENABOU Soureiyatou ${ }^{1}$ (1) $\cdot$ MFAYAKOUO Bachirou Chavom ${ }^{2} \cdot$ NDJIGUI Paul-désiré $^{3}$
}

Received: 30 May 2020 / Accepted: 27 October 2020 / Published online: 22 November 2020

(c) Springer Nature Switzerland AG 2020

\begin{abstract}
Ten (10) bulk samples of four sequences were collected at the left and the right banks of Ngaye River (North Cameroon), to assess their origin, depositional conditions and paleoclimate. For this purpose, granulometric, mineralogical and geochemical analysis were performed. The sediments are sandy-clayey, silty-clayey to clayey which are exclusively made up of kaolinite, quartz, illite, accessory muscovite, feldspars, anatase and goethite. $\mathrm{La} / \mathrm{Sc}$, Th/Sc, Th/Co, Th/Cr concentration ratios suggested that these sediments were derived from UCC. The bivariate plots diagrams of Hf versus La/Th and La/SC versus $\mathrm{Co} / \mathrm{Th}$ show that Ngaye alluvial sediment is mainly composed with acidic source rock and old sedimentary rock. Additionally, the diagram of $\Sigma$ REE versus La/Yb suggested that these sediments derived from alkali basalts, sedimentary and granites rocks. The correlation matrix implies that the distribution of trace elements in the analysed sequence samples shows a good correlation in the majority of the samples. Correlation coefficients between trace elements and total REE of the studied sequences indicate that REEs of the Ngaye alluvial sediments are mainly from the terrigenous formations. Discriminant diagrams, consisting of La-Th-Sc and Th-Co-Zr/10, suggest that the Ngaye alluvial sediment was deposited in continental island arc tectonic setting. Redox proxies $(\mathrm{V} / \mathrm{Ni}, \mathrm{V} /(\mathrm{V}+\mathrm{Ni})$ suggested that anoxic depositional condition was prevailed during deposition of the Ngaye alluvial deposit. The $\mathrm{Ga} / \mathrm{Rb}$ ratio values range from 0.19 to 1.47 whereas those of $\mathrm{Sr} / \mathrm{Cu}$ ratio range from 2.81 to 29.34 , suggested that Ngaye area was characterized by dry and humid climate condition during the depositional period.
\end{abstract}

Keywords Trace elements · Rare earth elements · Depositional condition · Paleoclimate · Ngaye

\section{Introduction}

Several works revealed that there are contrast behaviour between trace elements and rare earth element (REE). Some immobile elements such as $\mathrm{Al}, \mathrm{Ti}, \mathrm{Zr}$, Th and $\mathrm{REE}$ are usually concentrated in the fine-grained sediments because their hosted minerals, including accessory primary minerals and secondary minerals, occur in this fraction size. These elements tend to concentrate in the suspended load of the river $[1,2]$. Rare earth elements (REEs) and particularly TiO2 among other major elements can be used to determine geological processes, the tectonic setting and provenance of clastic sediments [3]. Some authors used trace element behaviour to understand the provenance, the sorting and the depositional history of sediments (e.g., [4, 5]). The genesis and depositional

FADIL-DJENABOU Soureiyatou, soureiyatou@yahoo.fr; MFAYAKOUO Bachirou Chavom, bachirou.mfayakouo@univ.maroua.cm; mfayakouo@yahoo.fr; NDJIGUI Paul-désiré, Indjigui@yahoo.fr | 'Department of Live and Earth Sciences, Higher Teacher's Training College, University of Maroua, P.O. Box. 55, Maroua, Cameroon. ' 2 Laboratory of Geosciences and sustainable development, Faculty of Science, University of Maroua, P.O. Box. 814, Maroua, Cameroon. ${ }^{3}$ Department of Earth Sciences, Faculty of Science, University of Yaoundé I, P.O. Box 812, Yaounde I, Cameroon. 
environment of clastic sediments depend on the nature of source rocks, weathering degree, climate, erosion action and the morphology of the region $[4,6]$. Similarly, some trace elements (e.g. $\mathrm{V}, \mathrm{Ni}, \mathrm{Co}$ ) of fine-grained sediments are also used as effective tracers of paleoclimate and depositional environments $[7,8]$. Moreover, the geochemical characteristics of fine-grained sediments that record the information of paleoclimate are greatly affected by the depositional conditions (Xu et al. 2010 [9], [8]). In Central Africa, few studies focused on trace elements and/or REE geochemical method for deciphering provenance, depositional conditions and paleoclimate reconstitution. [10]. Therefore, the use of concentrations and distribution of REE and trace elements is critically important for the determination of the source rocks, environment of deposition as well as paleoclimatic condition of the clastic sediments within this area. Provenance of the Ngaye alluvial sediment has been in the past suggested as well as heavy mineral concentration [1]. However, depositional environment and paleoclimatic conditions of this deposit remain unknown till today. This paper presents trace elements and REE data from four deposition sequences of the Ngaye area. Accordingly, this work aims at discussing the use of trace elements and REEs geochemical methods for deciphering origin, depositional conditions and paleoclimate reconstitution, as well as their tectonic setting. Additionally, to better highlight the distribution of trace and REEs elements in the Ngaye alluvial sediments, statistical methods were also applied.

\section{Geological setting}

The Ngaye alluvial deposits are located in North Cameroon with stems for the Northern border of the Adamawa plateau, between $7^{\circ} 13^{\prime}-7^{\circ} 14^{\prime} \mathrm{N}$ and $15^{\circ} 26^{\prime}-15^{\circ} 28^{\prime} \mathrm{E}$, covering $151 \mathrm{~km}^{2}$ in the North of the Cretaceous Mbere Trough (Fig. 1). The climate is sub-tropical, with main annual rainfall of about $970 \mathrm{~mm}$ and a main annual temperature of about $27^{\circ} \mathrm{C}$. The vegetation is a savannah type with a dense (gallery) forest fringing some of the rivers [11]. The Cretaceous Mbere Trough is a deep trough between the border of the Adamawa Plateau in the North and the prolongation in Cameroon of the Yade Massif in Central African Republic, to the South (Fig. 1b). The Adamawa-Yade massif is dominated by

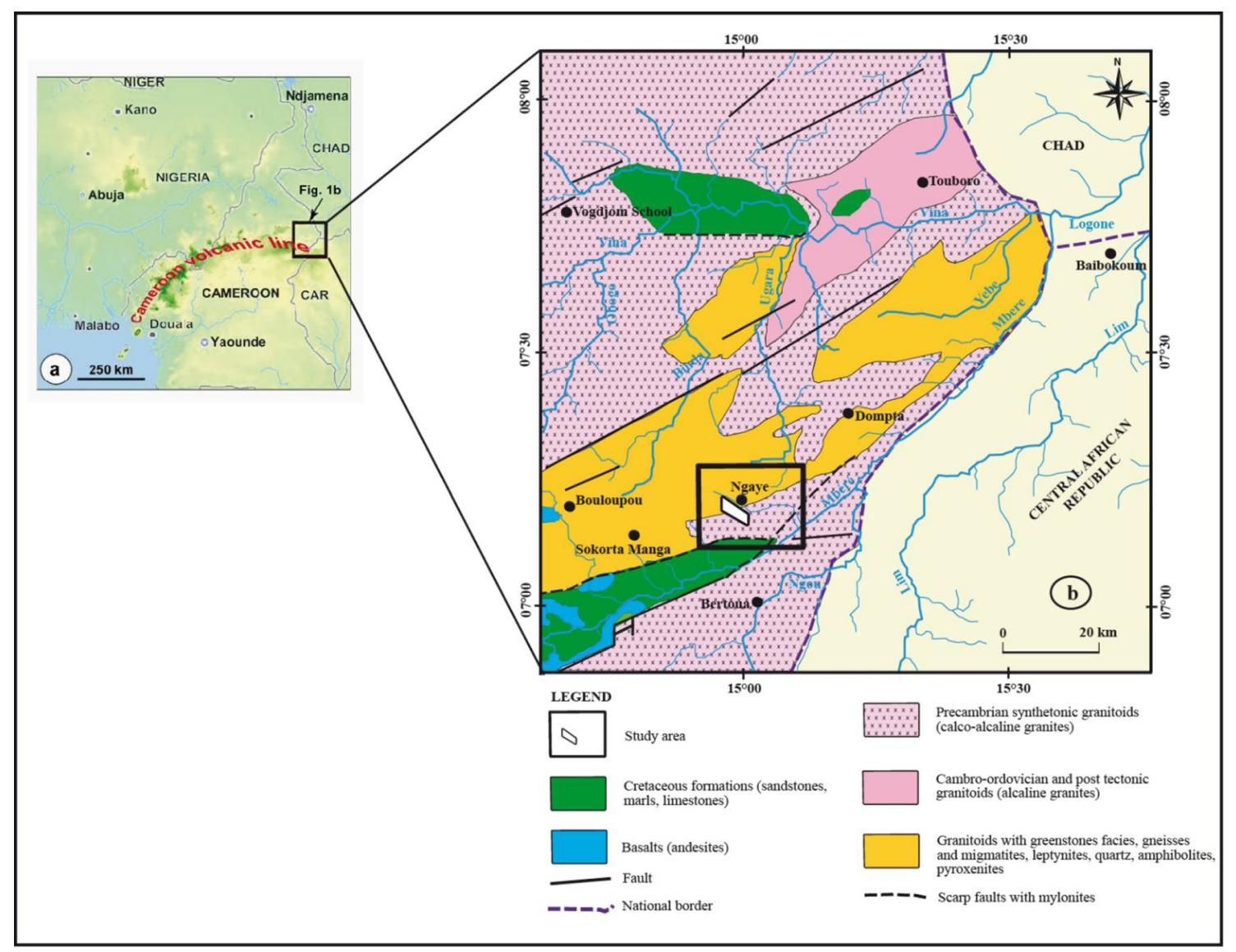

Fig. 1 a Location of the study area b Combined geological map of the study area (geological map adapted from Le Maréchal (1976) in [1] 
a NE-SW elongated regional-scale plutonic complexes intrusion into a Paleoproterozoic basement and locally covered by Cretaceous deposits [1] and by Cenozoic rocks in the Cameroon Volcanic Line (Fig. 1a). The Adamawa-Yade batholith consists of a great variety of more or less deformed rock-types of different ages. The Adamawa plateau is an extension of the southern part of the Yade massif of the Central African Republic in Cameroon. The domain of Adamawa-Yade of Cameroon is dated Archaean and Paleoproterozoic. It is juxtaposed by the Neoproterozoic domain of West Cameroon, in its western part, is the Tibati-Banyo fault and in the South the Adamawa faults and the Neoproterozoic trench of Yaoundé. This area includes Paleoproterozoic relics totally or partially transformed by amphibolites during the Pan-African orogeny. The various lithologies include granites, diorites, gabbros and syenites [12]. The granites were emplaced into a ca. 2.1 Ga remobilized basement composed of sedimentary and meta-igneous rocks that later underwent medium-to-high grade Pan-African metamorphism [12]. The basement of the Ngaye region is mainly constituted of metamorphic rocks like gneiss, amphibolites and quartzites there are also plutonic rocks principally granites. The soils are essentially ferruginous [13], and the geomorphology comprises wide valleys dominated by symmetric hills [11]. The investigated clayed material is located at $7^{\circ} 14^{\prime} 35 \mathrm{~N}$ and $15^{\circ} 24^{\prime} 40 \mathrm{E}$ (Fig. 1a).

\section{Materials and methods}

\subsection{Sample collection and preparation}

Two sequences of sediments ( $A$ and $B$ ) at the left and two $(C$ and $D)$ at the right banks of Ngaye River were selected (Fig. 2). Ten (10) bulk samples were collected according to the different colour of the layers. One hundred grams $(100 \mathrm{~g})$ of each sample was collected for analyses and was split up and prepared homogenously for granulometric mineralogical and chemical analysis. Grain size was measured according to the standard pipetting method for the silt- and clay-sized fractions. For this, the sample is dried in the open air after sifting with a sieve of $2 \mathrm{~mm}$ in diameter,
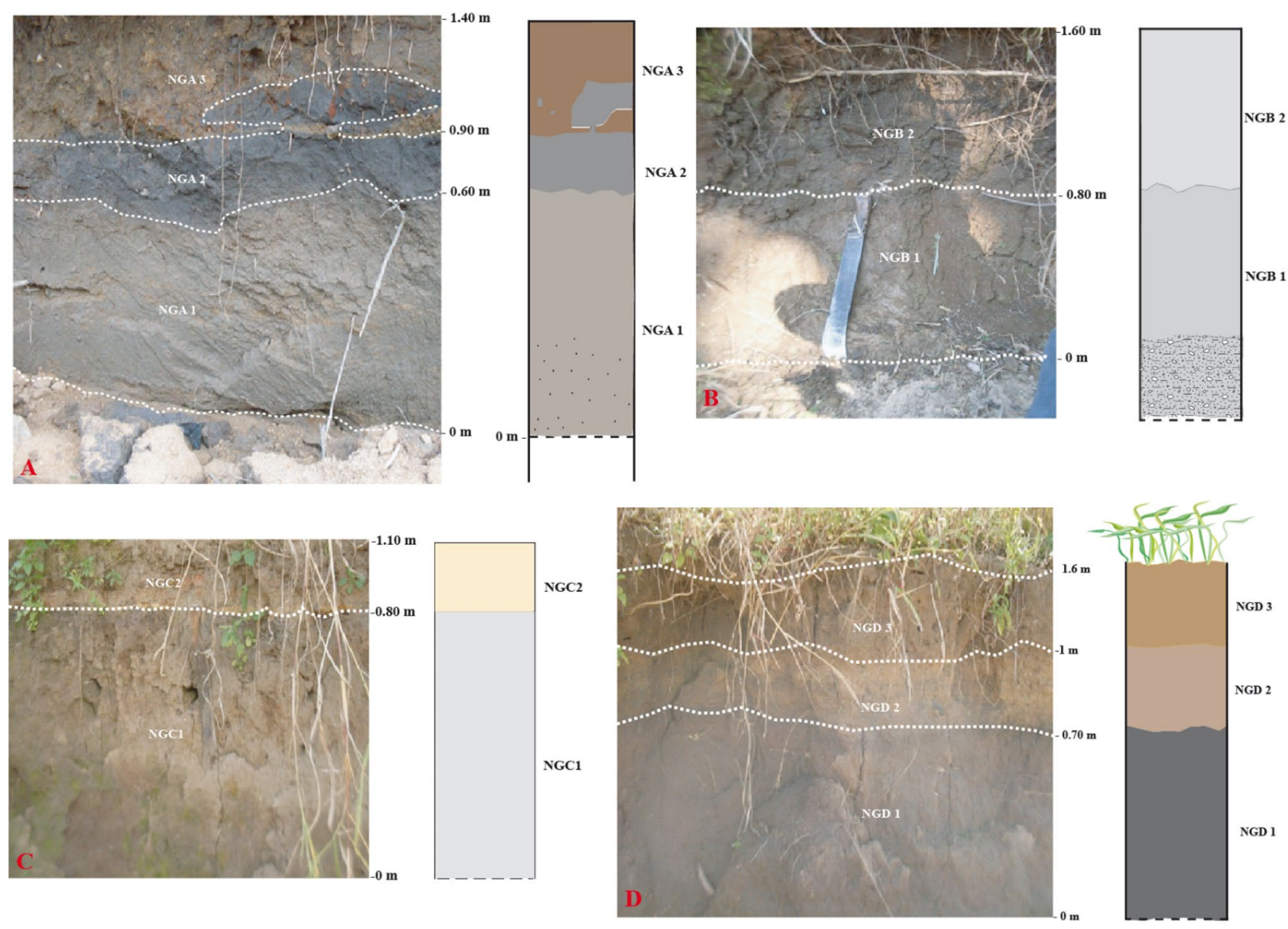

Fig. 2 Outcrop of the Ngaye alluvial deposits and vertical cross section presenting different sedimentary layers with the samples position 
$20 \mathrm{~g}$ of material is taken. Organic matter was destroyed, by moistening the material with distilled water, and adding $25 \mathrm{ml}$ of bleach ( $\mathrm{NaClO} 47-50 \mathrm{c}$ ) the solution obtained was placed in the oven at $40^{\circ} \mathrm{C}$ for $24 \mathrm{~h}$. After $24 \mathrm{~h}$, the sample is removed from the pan, then dispersed, with distilled water and $10 \mathrm{ml}$ of sodium hexametaphosphate (NaPO3) (Molecular weight: 101.96), distilled water is added until it reaches $1000 \mathrm{ml}$, then it was placed on the agitator for $2 \mathrm{H}$. The solution is taken 3 times for specific duration: Just after the mechanical agitation, the sample is removed, stirred and piped with a $20 \mathrm{ml}$ pipette after $46 \mathrm{~s}$. The second pipetting is after $4 \mathrm{~min} 48 \mathrm{~s}$ after shaking it. The third pipetting is after $8 \mathrm{~h}$ without shaking. Sand fractions were obtained with the remaining solution. Samples were, dried and sieved with a 200 sieve for coarse sands and 50 for fine sands. Collected solutions are placed on the steam at $40^{\circ} \mathrm{C}$ for drying after withdrawal, the gathered solutions are placed on the steam at $40^{\circ} \mathrm{C}$ for drying, then the samples are measured, preliminarily knowing the weight of the plate containing each sample the weight of the dry sample is determined, and then the percentage of each sample is also determined. Five samples $(20 \mathrm{~g}$ of the global fraction, $20 \mathrm{~g}$ of the coarse sand, $20 \mathrm{~g}$ of the fraction of fine sand, $20 \mathrm{~g}$ of the fraction of silt and $20 \mathrm{~g}$ of the clayish fraction) have been sent in geosciences laboratories in Sudbury (Canada) for mineralogic and geochemic analysis.

\subsection{Samples analyses}

The mineral assemblages were identified by $X$-ray diffraction after mounting the samples on glass. X-ray diffraction was performed on samples with Philips theta-2tetha (PW1050/81, PW3710) equipped by a monochromator with cobalt anticathode (Co-Ka=1.7854 $\AA$ ). For a trace and rare earth elements, samples were crushed using a jaw crusher with steel plates and pulverized in a ball mill made of $99.8 \% \mathrm{Al}_{2} \mathrm{O}_{3}$ at the Geoscience Laboratories (Sudbury, Canada). Powder was digested by acid attack in closed beakers by inductively coupled plasma mass spectrometry analysis for lithophile trace element concentrations. Powder was treated in a mixture of $\mathrm{HCl}$ and $\mathrm{HClO} 4$ at $120^{\circ} \mathrm{C}$ in sealed teflon containers for one week, after which they were rinsed out of its containers with dilute $\mathrm{HNO}_{3}$ and dried. The residue was again dissolved in a mixture of three acids $\left(\mathrm{HNO}_{3}, \mathrm{HCl}\right.$ and $\left.\mathrm{HF}\right)$ at $100^{\circ} \mathrm{C}$. Sample solutions were analysed in a Perkin Elmer Elan 9000 ICP-MS instrument.

\subsection{Statistical analysis}

In this paper, correlation matrix and agglomerative hierarchical clustering (AHC) were performed between geochemical parameters such as elemental trace and REEs in order to establish the correlation and similarity or dissimilarity between these parameters. The Pearson's correlation coefficient was used to show the interrelationship and coherence pattern among geochemical parameters of the studied samples. Considering the specificity of the current study, the strong value of correlation matrix is 0.89 because it takes into account only ten samples. Cluster analysis given by AHC was applied to study the relationship between trace elements.

\section{Results}

\subsection{Lithological description}

Sequence $A$ is $1.40 \mathrm{~m}$ thick and has grey colour. It is made up of three layers (Fig. 2a). The bottom (NGA3) layer has a grey colour with $0.60 \mathrm{~m}$ thick, having little roots as compared to the two underlying layers. The middle layer (NGA2) is dark grey clay with 0.40 m thick with a sandy structure, and it is marked by a change of colour and the presence of millimetric root twigs. The top layer (NGA3) is $0.40 \mathrm{~m}$ thick with grey brown colour and a coarse massive structure with coloured grains. This layer carries vegetation composed of grasses and shrubs. It is crossed by roots with dark grey clay past. The three layers have similar sand proportion but different clay and silt proportion particle (Table 1). Sand and clay proportions are most abundant conferring a sandy clay texture to the sequence.

Sequence B has two layers (Fig. 2b): the bottom layer (NGB1) is $0.80 \mathrm{~m}$ thick and loam-grey in structure with dark reddish brown colour, containing flakes of micas. The top layer (NGB2) is $0.80 \mathrm{~m}$ thick with dark grey colour and contains altered mica flakes, quartz grains and numerous millimetric roots. The materials of sequence $B$ have high silt contents compared to those of sequence $A$. The highest content is the one of the bottom layer sample (39.93 wt

Table 1 Particle size distribution (wt \%) of Ngaye sediments samples

\begin{tabular}{lllcl}
\hline Sequences & Samples & Clay & Silt & Sand \\
\hline A & NGA1 & 43.15 & 0.83 & 55.49 \\
& NGA2 & 33.93 & 8.24 & 57.81 \\
& NGA3 & 27.30 & 16.5 & 55.90 \\
B & NGB1 & 15.49 & 39.93 & 48.00 \\
& NGB2 & 22.95 & 20.47 & 53.83 \\
C & NGC1 & 43.24 & 1.63 & 55.03 \\
& NGC2 & 41.00 & 0.92 & 58.01 \\
D & NGD1 & 35.39 & 6.73 & 57.85 \\
& NGD2 & 34.80 & 2.91 & 62.00 \\
& NGD3 & 41.12 & 11.70 & 45.00 \\
\hline
\end{tabular}


$\%)$ while its proportion in clay is low (15.49 wt \%). Sand contents conferred silty-clayed texture.

Sequence $C$ is $1.10 \mathrm{~m}$ thick and is made up of two layers: the bottom layer (NGC1) has $0.80 \mathrm{~m}$ of thickness and brown in colour. The top layer (NGC2) has $0.30 \mathrm{~m}$ of thickness, dark yellowish brown with fine sandy laminations. Both layers are characterized by a clayey sand texture (Fig. 2C). The clay contents are higher in this profile $(<40 \%)$ as compared to silt contents (Table 1).

Three layers constitute sequence $D$ with thickness of about $1.60 \mathrm{~m}$ (Fig. 2d). The bottom layer (NGD1) which has $0.70 \mathrm{~m}$ of thickness, is clayey sand and has grey colour. The middle layer (NGD2) has $0.30 \mathrm{~m}$ of thickness with light brown colour and finally the upper layer (NGD3) which is $0.60 \mathrm{~m}$ thick colours reddish brown. Grain size particles of the three layers show sandy clay textures (Table 1).

$\mathrm{X}$-ray diffractometry reveals the presence of kaolinite, smectites, illite-muscovite, vermiculite and goethite but also quartz, feldspars, pyroxene, anatase and amphibole (Fig. 3). Sequences B and D have high proportions of clay minerals including kaolinite and smectites (Fig. 3b, d). In contrast, Sequences $A$ and $C$ contain traces of smectites and abundance of kaolinite (Fig. 3c). Vermiculite is present in the upper layer (NGB2) of Profile B. Quartz, feldspars and illite-muscovite is abundant in all profiles (Fig. 3).

\subsection{Distribution of trace elements}

Distribution of trace elements varies from one sequence to another. Analytical results are indicated in Table 2. Trace elements of the first transition group have high concentrations in the bottom and top levels. For sequences $B$ and $C$, they are slightly higher at the top of the sequence, with the exception of scandium. The highest values (29.10 ppm) are in the top of sequence $A$ and their lowest values $(7 \mathrm{ppm})$ is in the middle of sequence $D$. Elements
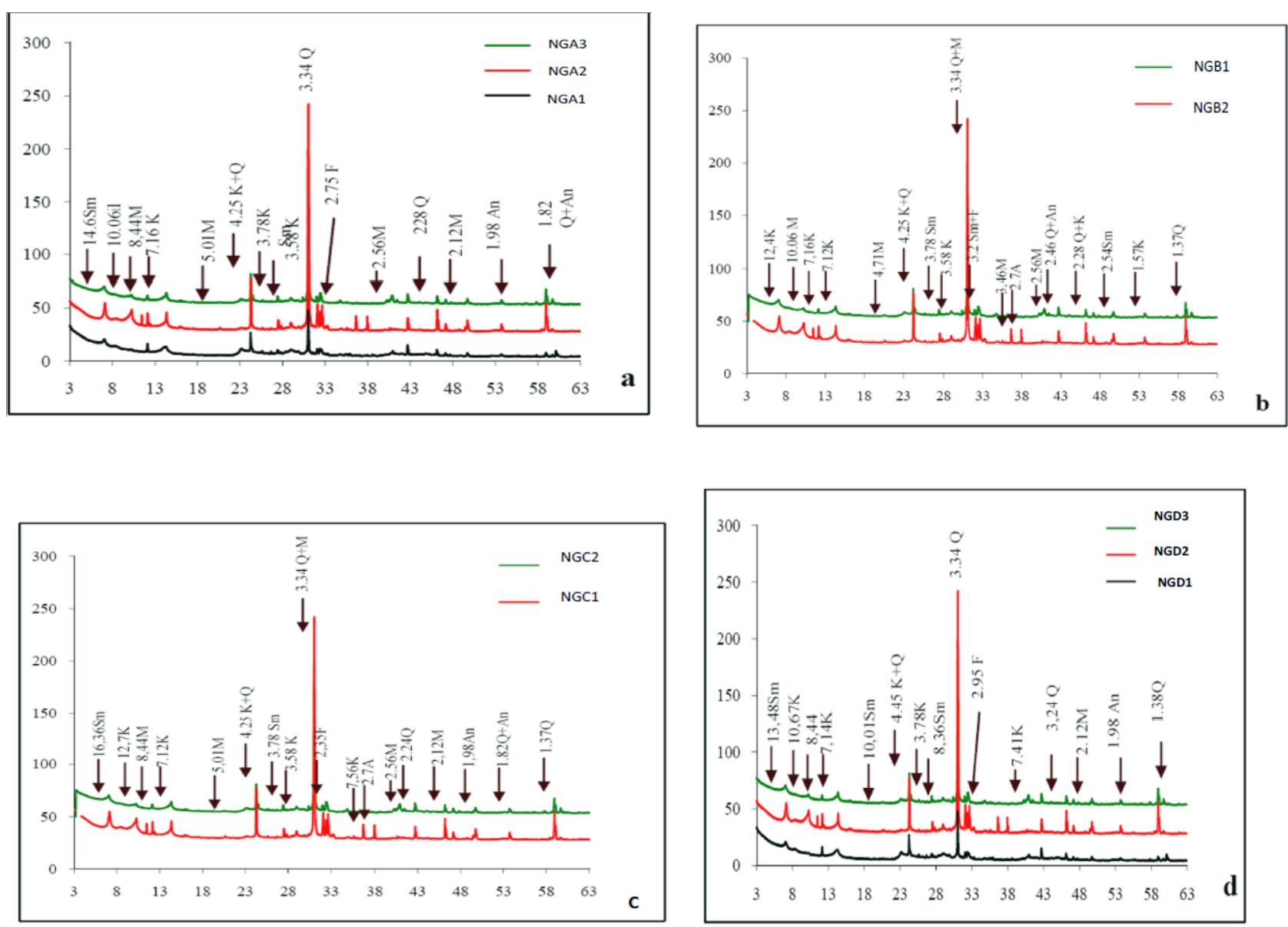

$\mathrm{K}=$ Kaolinite; $\mathrm{M}=$ Muscovite; $\mathrm{Q}=$ Quartz; $\mathrm{Sm}=$ Smectites $; \mathrm{F}=$ Feldspaths ; An= Anatase ; Il= Illite

Fig. 3 X-ray diffraction spectra of sediments. a Sequence A (NGA1: bottom layer; NGA2: middle layer and NGA3: top layer); $\mathbf{b}$ sequence B (NGY1: bottom layer; NGY2: top layer); c sequence C (NGA1: bot- tom layer; NGA2: top layer); d sequence (NGB1: bottom layer; NGB2: middle layer and NGB3: top layer) 
Table 2 Trace element concentration of the Ngaye alluvial clay deposits (ppm)

\begin{tabular}{|c|c|c|c|c|c|c|c|c|c|c|c|}
\hline & \multicolumn{4}{|c|}{ Sequence A } & \multicolumn{2}{|c|}{ Sequence B } & \multicolumn{2}{|c|}{ Sequence C } & \multicolumn{3}{|c|}{ Sequence D } \\
\hline & d.I & NGA1 & $\mathrm{NGA} 2$ & NGA3 & NGY1 & NGY2 & NGC1 & NGC2 & NGD1 & NGD2 & NGD3 \\
\hline $\mathrm{Cr}$ & 3.00 & 135 & 68.00 & 80.00 & 101 & 101 & 96.00 & 114 & 90.00 & 49.00 & 108 \\
\hline V & 0.80 & 116 & 68.70 & 86.60 & 111 & 106 & 93.40 & 110 & 97.90 & 49.40 & 119 \\
\hline $\mathrm{Ni}$ & 1.60 & 73.20 & 27.70 & 37.60 & 42.30 & 47.20 & 47.00 & 55.30 & 39.40 & 18.70 & 42.60 \\
\hline$Z n$ & 7.00 & 72.00 & 40.00 & 43.00 & 56.00 & 61.00 & 57.00 & 67.00 & 51.00 & 25.00 & 444 \\
\hline $\mathrm{Cu}$ & 1.40 & 49.50 & 20.60 & 29.10 & 36.80 & 37.90 & 35.52 & 42.00 & 33.90 & 14.90 & 40.20 \\
\hline Co & 0.13 & 24.85 & 14.31 & 16.43 & 16.34 & 23.68 & 20.29 & 21.18 & 21.94 & 8.45 & 19.67 \\
\hline Sc & 1.10 & 14.50 & 8.30 & 29.10 & 13.60 & 13.90 & 11.10 & 13.40 & 13.30 & 7.00 & 15.30 \\
\hline $\mathrm{Ba}$ & 0.80 & 948 & 899 & 16.43 & 933 & 1035 & 1237 & 1247 & 817 & 863 & 801 \\
\hline $\mathrm{Zr}$ & 6.00 & 149 & 321 & 10.10 & 396 & 315 & 228 & 189 & 287 & 310 & 444 \\
\hline $\mathrm{Sr}$ & 0.60 & 147 & 144 & 854 & 131 & 166 & 226 & 251 & 102 & 125 & 113 \\
\hline Y & 0.05 & 15.90 & 11.70 & 330 & 21.02 & 20.09 & 14.64 & 15.38 & 19.37 & 11.25 & 24.04 \\
\hline $\mathrm{Li}$ & 0.40 & 26.01 & 5.30 & 133 & 11.60 & 11.60 & 10.00 & 11.90 & 10.20 & 5.20 & 10.90 \\
\hline Ga & 0.04 & 17.20 & 12.95 & 17.19 & 19.41 & 19.72 & 18.24 & 20.88 & 17.27 & 9.85 & 20.85 \\
\hline $\mathrm{Pb}$ & 0.60 & 41.73 & 13.20 & 8.40 & 16.90 & 15.30 & 15.20 & 16.00 & 14.00 & 13.00 & 14.70 \\
\hline $\mathrm{Rb}$ & 0.23 & 11.71 & 43.83 & 16.05 & 89.27 & 77.60 & 56.64 & 66.72 & 73.30 & 51.72 & 94.02 \\
\hline $\mathrm{Nb}$ & 0.03 & 3.84 & 10.26 & 15.00 & 12.88 & 12.13 & 8.31 & 8.75 & 11.98 & 6.86 & 15.24 \\
\hline $\mathrm{Hf}$ & 0.14 & 0.78 & 8.50 & 36.90 & 10.11 & 7.91 & 5.33 & 4.59 & 7.30 & 8.55 & 10.81 \\
\hline Mo & 0.08 & 14.51 & 0.69 & 10.02 & 1.41 & 1.22 & 0.61 & 0.65 & 2.14 & 0.79 & 1.82 \\
\hline Th & 0.02 & 1.21 & 17.12 & 9.15 & 20.27 & 15.85 & 11.22 & 11.49 & 15.53 & 18.06 & 19.42 \\
\hline U & 0.01 & 0.61 & 20.41 & 0.85 & 1.89 & 1.43 & 0.91 & 0.87 & 1.39 & 1.31 & 1.77 \\
\hline $\mathrm{Ta}$ & 0.02 & 1.72 & 0.84 & 13.48 & 0.78 & 0.73 & 0.41 & 0.42 & 0.76 & 0.51 & 0.97 \\
\hline $\mathrm{Be}$ & 0.04 & 0.07 & 0.60 & 1.47 & 1.07 & 1.27 & 1.25 & 1.53 & 0.20 & 0.56 & 0.92 \\
\hline $\mathrm{Cd}$ & 0.01 & 0.76 & 0.56 & 0.61 & 0.05 & 0.05 & 0.05 & 0.06 & 0.06 & 0.05 & 0.08 \\
\hline Cs & 3.00 & 0.06 & 0.34 & 0.55 & 0.66 & 0.59 & 0.48 & 0.51 & 0.58 & 0.24 & 0.63 \\
\hline Sn & 0.16 & 0.38 & 0.84 & 1.00 & 1.23 & 1.23 & 1.24 & 1.44 & 0.94 & 0.52 & 1.07 \\
\hline W & 0.05 & 0.33 & 0.40 & 0.40 & 0.39 & 0.36 & 0.25 & 0.24 & 0.37 & 0.25 & 0.53 \\
\hline TI & 0005 & 0.05 & 0.26 & 0.29 & 0.39 & 0.33 & 0.25 & 0.27 & 0.34 & 0.22 & 0.40 \\
\hline $\mathrm{V} / \mathrm{Ni}$ & - & 2.3 & 2.48 & 1.58 & 2.25 & 2.62 & 1.98 & 1.99 & 2.78 & 2.64 & 2.48 \\
\hline $\mathrm{V} /(\mathrm{V}+\mathrm{Ni})$ & - & 0.7 & 0.71 & 0.61 & 0.69 & 0.72 & 0.66 & 0.66 & 0.73 & 0.72 & 0.71 \\
\hline $\mathrm{V} / \mathrm{Cr}$ & - & 1.08 & 1.01 & 0.86 & 1.05 & 1.1 & 0.96 & 0.97 & 1.1 & 1.01 & 1.09 \\
\hline $\mathrm{Ni} / \mathrm{Co}$ & - & 2.28 & 1.93 & 2.94 & 1.99 & 2.57 & 2.61 & 2.31 & 2.16 & 2.21 & 1.79 \\
\hline $\mathrm{Sr} / \mathrm{Cu}$ & - & 29.34 & 7.02 & 2.99 & 4.37 & 3.57 & 5.97 & 6.36 & 2.81 & 8.4 & 3.01 \\
\hline $\mathrm{Ga} / \mathrm{Rb}$ & - & 1.07 & 0.29 & 1.47 & 0.25 & 0.22 & 0.31 & 0.32 & 0.22 & 0.19 & 0.23 \\
\hline Th/U & - & 10.76 & 0.84 & 1.98 & 11.08 & 10.72 & 13.2 & 12.32 & 10.97 & 13.78 & 11.17 \\
\hline $\mathrm{Th} / \mathrm{Sc}$ & - & 0.08 & 2.06 & 0.79 & 1.49 & 1.14 & 1.01 & 0.86 & 1.17 & 2.58 & 1.27 \\
\hline Th/Co & - & 0.05 & 1.19 & 0.56 & 0.55 & 0.54 & 0.71 & 0.54 & 0.71 & 2.14 & 1.16 \\
\hline $\mathrm{Th} / \mathrm{Cr}$ & - & 0.01 & 0.25 & 0.11 & 0.20 & 0.16 & 0.17 & 0.12 & 0.20 & 0.37 & 0.18 \\
\hline
\end{tabular}

such as $\mathrm{Cr}, \mathrm{Ni}$, $\mathrm{Cu}$ and $\mathrm{Co}$ have higher concentration in the bottom of sequence $A$ and the lowest in the middle of sequence $D$. The $C r$ values varies between $49,135 \mathrm{ppm}$, the $\mathrm{Ni}$ values varies between 18.70, $73.20 \mathrm{ppm}$, the $\mathrm{Cu}$ values varies between 18.70 , and $72 \mathrm{ppm}$ and the Co values varies between 8.45 and 24.85 ppm (Table 2). The concentrations of the second transition group are from moderate to low. The lowest values are in the middle of sequences $A$ and $B$ and at the top of sequences $B$ and $C$ (Table 2). Except for $\mathrm{Zn}$ with the high values (444 ppm) in the top of the sequence $D$, the other elements of the first series have concentrations less than 25 ppm (Table 2). The concentrations of large ion lithophile elements (LILE) like $\mathrm{Ba}$, $\mathrm{Sr}, \mathrm{Li}, \mathrm{Rb}$ and $\mathrm{Be}$ vary between one profile to another. The Ba values vary between 166.43 and 1247 ppm; the lowest value is found in the top of sequence $A$, and the highest in the top of sequence $C$. Strontium values vary between 102 and $854 \mathrm{ppm}$; the lowest value is at the bottom of sequence $D$, and the highest values at the top of sequence $\mathrm{A}$. The $\mathrm{Li}, \mathrm{Rb}$ and Be have moderate to low concentrations, their values vary between 5 and 133 ppm. For $U$ and Th, 
their concentrations are lower than those elements in the studied deposition sequences (Table 2).

According to Bach and Irber [14], terrigenous and/or biogenic flux, sedimentation processes, diagenesis and some unknown factors mainly control distribution of the trace elements in sediments. In order to distinguish these complex effects, factors and processes, multivariate statistical method like correlation matrix (CM) and agglomerative hierarchical clustering (AHC) analysis were applied. This method can reveal similarities and/or dissimilarities in distribution of different elements within the studied sequences. The result of correlation matrix (CM) implies that the distribution of element in the samples of analysed sequences shows a very good correlation in the majority of the sample except the sample NGA3 which shows very poor correlation ( $r$ varies between 0.030 and 0.124 ) with others samples of the analysed profiles (Table 3 ).

The agglomerative hierarchical clustering (AHC) analysis has shown six classes of elements grouped in two strongly distinct clusters and two sub-clusters, based on the visual observation of the dendrogram (Fig. 4). These revealed dissimilarity in the distribution of different elements within the studied profiles. The cluster I groups elements of class 4 represent by $\mathrm{Ba}$. The cluster $2 \mathrm{~A}$ regroups elements of class 1,2 and 3 which characterized the element of first and second transition group, the
Table 3 Correlation matrix (Pearson)
Fig. 4 Dendrogram of Hierarchical Cluster Analysis, based on trace elements

\begin{tabular}{lllllllllll}
\hline & NGA1 & NGA2 & NGA3 & NGB1 & NGB1 & NGC2 & NGC2 & NGD1 & NGD2 & NGD3 \\
\hline NGA1 & 1 & - & - & - & - & - & - & - & - & - \\
NGA2 & 0.074 & 1 & - & - & - & - & - & - & - & - \\
NGA3 & 0.090 & 0.974 & 1 & - & - & - & - & - & - & - \\
NGB1 & 0.078 & 0.997 & 0.984 & 1 & - & - & - & - & - & - \\
NGB2 & 0.056 & 0.995 & 0.962 & 0.993 & 1 & - & - & - & - & - \\
NGC1 & 0.124 & 0.978 & 0.993 & 0.988 & 0.962 & 1 & - & - & - & - \\
NGC2 & 0.105 & 0.985 & 0.992 & 0.992 & 0.970 & 0.999 & 1 & - & - & - \\
NGD1 & 0.030 & 0.895 & 0.860 & 0.894 & 0.909 & 0.853 & 0.860 & 1 & - & - \\
NGD2 & 0.061 & 0.999 & 0.969 & 0.996 & 0.995 & 0.976 & 0.984 & 0.890 & 1 & - \\
NGD3 & 0.054 & 0.993 & 0.975 & 0.994 & 0.996 & 0.972 & 0.977 & 0.901 & 0.992 & 1 \\
\hline
\end{tabular}

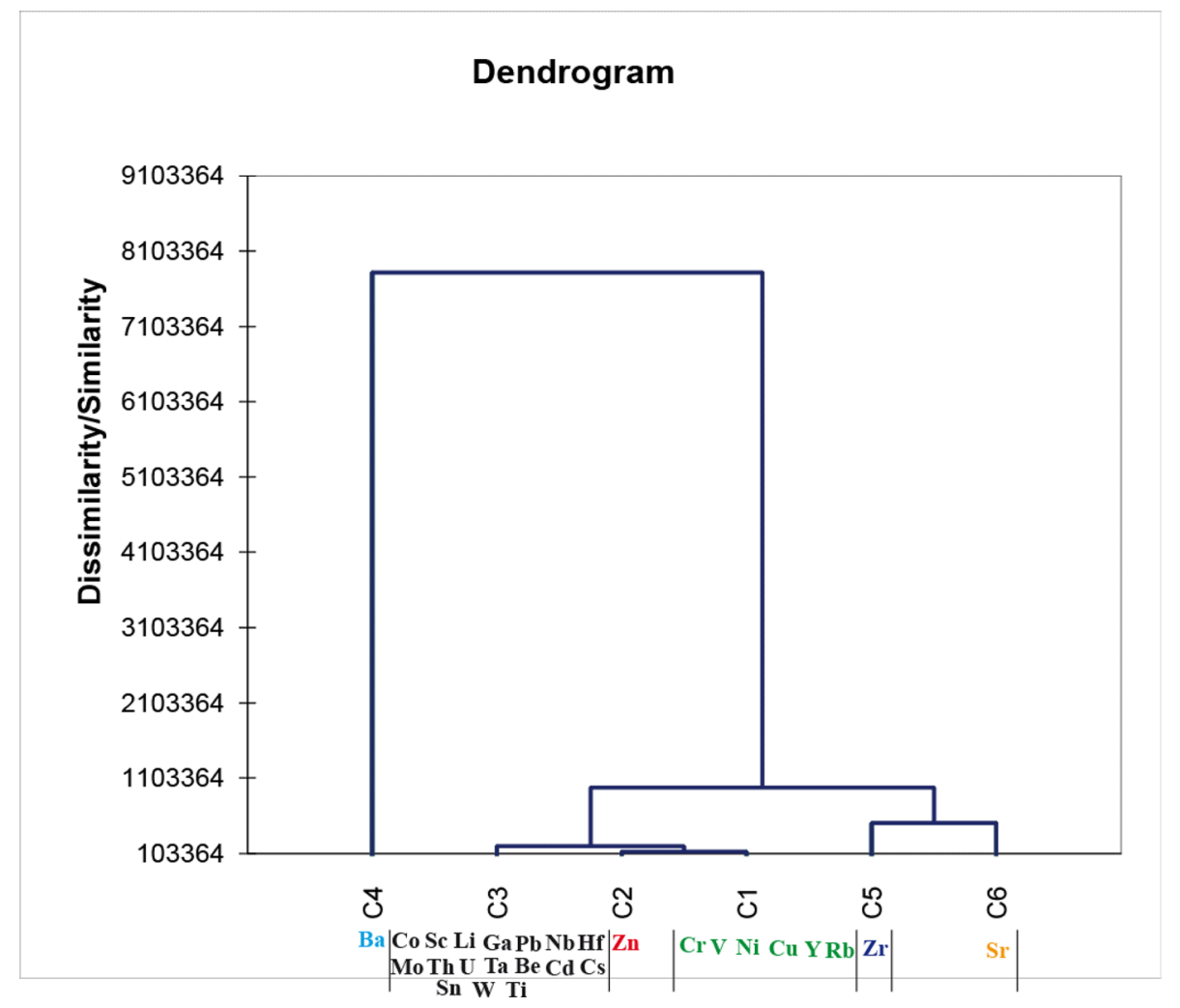


LILE such as $\mathrm{Sr}, \mathrm{Y}, \mathrm{Hf}, \mathrm{Li}$ and others element which could indicate the influence of terrigenous detrital source provenance of these elements. Cluster 2B regroup element of class 5 and 6 represent by $Z r$ and Sr. The cluster I and $2 \mathrm{~B}$ group elements with the high concentrations $(\mathrm{Ba}$, $\mathrm{Sr}$ and $\mathrm{Zr}$ ) and their distribution in the different studied sequences can be the result of the sedimentary process.

\subsection{REE-distribution}

The concentrations of total REEs vary between 175 and $249 \mathrm{ppm}$ (Table 4) with an average of $211.68 \mathrm{ppm}$. The Ngaye alluvial sediments are relatively enriched in REE [1] when we compared the concentration of those from the North American Shale Composite [15] (NASC) (173.21 ppm). The average values of the LREE and HREE concentrations in the studied samples are 194 and 16.54, respectively, and the $\mathrm{LREE} / \mathrm{HREE}$ ratio is relatively high (5.72-17.45) which characterized relatively the high abundance of LREE in the Ngaye alluvial sediments. The NASCnormalized REE distribution pattern (Fig. 5) for the studied sequences shown that there is a significant enrichment of LREE and the right inclined REE pattern also revealing that the Ngaye alluvial sediments are enriched in LREE.

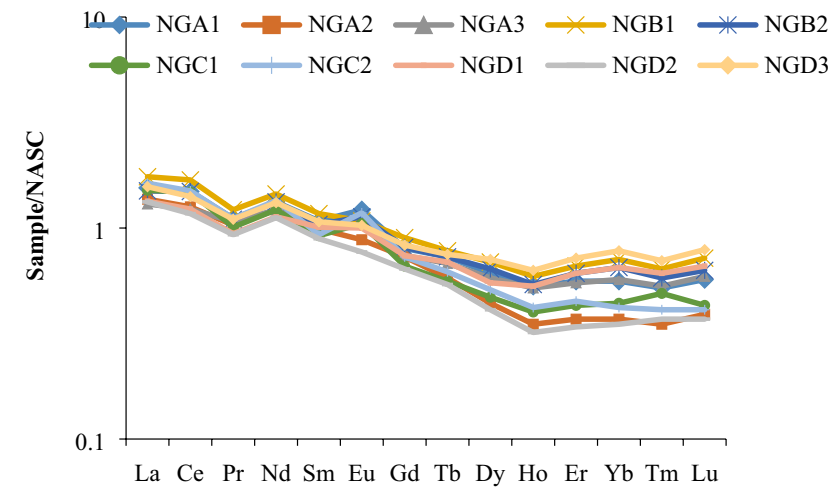

Fig. 5 NASC-normalized REE distribution pattern of Ngaye clay deposits

In the other hand, the concentrations of three light rare earth elements (lanthanum, cerium and neodymium) vary between 151 and $206 \mathrm{ppm}$. The ( $\mathrm{La}+\mathrm{Ce}+\mathrm{Nd}) / \Sigma \mathrm{REE})$ ratio varies from 0.62 to 0.87 , this ratio indicates that the three LREE are predominant in studied deposits. Among the LREE, cerium concentrations are the highest. These vary from 111 to $78.44 \mathrm{ppm}$. The maximum value is in the top
Table 4 REEs concentration of the Ngaye Alluvial clay deposits

\begin{tabular}{|c|c|c|c|c|c|c|c|c|c|c|c|}
\hline \multirow[b]{2}{*}{ Code } & \multirow[b]{2}{*}{ d.I } & \multicolumn{3}{|l|}{ Profil A } & \multicolumn{2}{|l|}{ Profil B } & \multicolumn{2}{|l|}{ Profil C } & \multicolumn{3}{|c|}{ Profil D } \\
\hline & & NGA1 & NGA2 & NGA3 & NGB1 & NGB2 & NGC1 & NGC2 & NGD1 & NGD2 & NGD3 \\
\hline La & 0.04 & 48.35 & 42.81 & 40.44 & 54.37 & 46.69 & 47.11 & 50.86 & 41.80 & 41.63 & 48.80 \\
\hline $\mathrm{Ce}$ & 0.12 & 99.70 & 84.44 & 81.45 & 111.40 & 98.25 & 98.07 & 99.57 & 82.37 & 78.44 & 94.66 \\
\hline $\operatorname{Pr}$ & 0.01 & 10.16 & 9.35 & 9.17 & 11.14 & 10.06 & 9.26 & 10.10 & 8.62 & 8.52 & 10.02 \\
\hline $\mathrm{Nd}$ & 0.06 & 36.61 & 33.42 & 33.62 & 39.93 & 36.42 & 33.52 & 36.49 & 31.10 & 30.82 & 36.31 \\
\hline Sm & 0.01 & 6.07 & 5.68 & 5.62 & 6.57 & 5.82 & 5.19 & 5.66 & 5.16 & 4.98 & 6.01 \\
\hline $\mathrm{Eu}$ & 0.003 & 1.49 & 1.04 & 1.27 & 1.28 & 1.34 & 1.25 & 1.39 & 1.19 & 0.92 & 1.22 \\
\hline Gd & 0.009 & 4.50 & 4.11 & 4.13 & 5.04 & 4.57 & 3.72 & 4.12 & 4.19 & 3.62 & 4.67 \\
\hline $\mathrm{Tb}$ & 0.002 & 0.62 & 0.50 & 0.58 & 0.67 & 0.62 & 0.48 & 0.53 & 0.59 & 0.46 & 0.64 \\
\hline Dy & 0.009 & 3.55 & 2.54 & 3.36 & 3.99 & 3.69 & 2.73 & 2.95 & 3.52 & 2.37 & 4.09 \\
\hline Ho & 0.002 & 0.67 & 0.46 & 0.66 & 075 & 0.69 & 0.51 & 0.54 & 0.68 & 0.41 & 0.80 \\
\hline $\mathrm{Er}$ & 0.007 & 1.90 & 1.24 & 1.84 & 2.20 & 2.06 & 1.46 & 1.51 & 2.05 & 1.16 & 2.42 \\
\hline $\mathrm{Tm}$ & 0.002 & 0.27 & 0.18 & 0.27 & 0.33 & 0.30 & 0.25 & 0.21 & 0.31 & 0.19 & 0.36 \\
\hline $\mathrm{Yb}$ & 0.009 & 1.72 & 1.15 & 1.76 & 2.17 & 1.99 & 1.36 & 1.30 & 2.00 & 1.09 & 2.40 \\
\hline Lu & 0.002 & 0.26 & 0.18 & 0.27 & 0.33 & 0.29 & 0.20 & 0.19 & 0.30 & 0.17 & 0.36 \\
\hline$\sum$ REE & - & 216 & 187 & 184 & 240 & 213 & 205 & 215 & 249 & 175 & 213 \\
\hline LREE & - & 203 & 177 & 172 & 213 & 199 & 175 & 204 & 234 & 165 & 197 \\
\hline HREE & - & 13.29 & 10.36 & 12.87 & 26.88 & 14.21 & 30.51 & 11.35 & 14.65 & 9.47 & 15.74 \\
\hline LREE/HREE & - & 15.24 & 17.06 & 13.33 & 7.93 & 13.97 & 5.72 & 17.97 & 15.96 & 17.45 & 12.51 \\
\hline$\Sigma(\mathrm{La}+\mathrm{Ce}+\mathrm{Nd})$ & - & 187 & 161 & 155 & 206 & 151 & 179 & 187 & 155 & 151 & 180 \\
\hline$\left(\mathrm{La} / \mathrm{La}^{*}\right) \mathrm{N}$ & - & 0.86 & 0.86 & 0.84 & 0.85 & 0.70 & 0.87 & 0.86 & 0.62 & 0.86 & 0.84 \\
\hline$\left(\mathrm{Ce} / \mathrm{Ce}^{*}\right) \mathrm{N}$ & - & 1.04 & 0.94 & 0.98 & 1.09 & 1.09 & 1.15 & 1.06 & 0.36 & 1.01 & 1.03 \\
\hline$\left(E u / E u^{*}\right) N$ & - & 1.08 & 0.99 & 1.01 & 1.12 & 1.06 & 0.89 & 0.93 & 1.02 & 0.86 & 1.09 \\
\hline$\left(\operatorname{Pr} / \operatorname{Pr}^{*}\right) \mathrm{N}$ & - & 1.34 & 1.33 & 1.24 & 0.67 & 0.79 & 0.86 & 0.78 & 0.73 & 0.66 & 0.70 \\
\hline $\mathrm{La} / \mathrm{Sc}$ & - & 3.34 & 5.16 & 1.39 & 3.40 & 3.36 & 4.24 & 3.79 & 3.14 & 5.95 & 3.19 \\
\hline
\end{tabular}




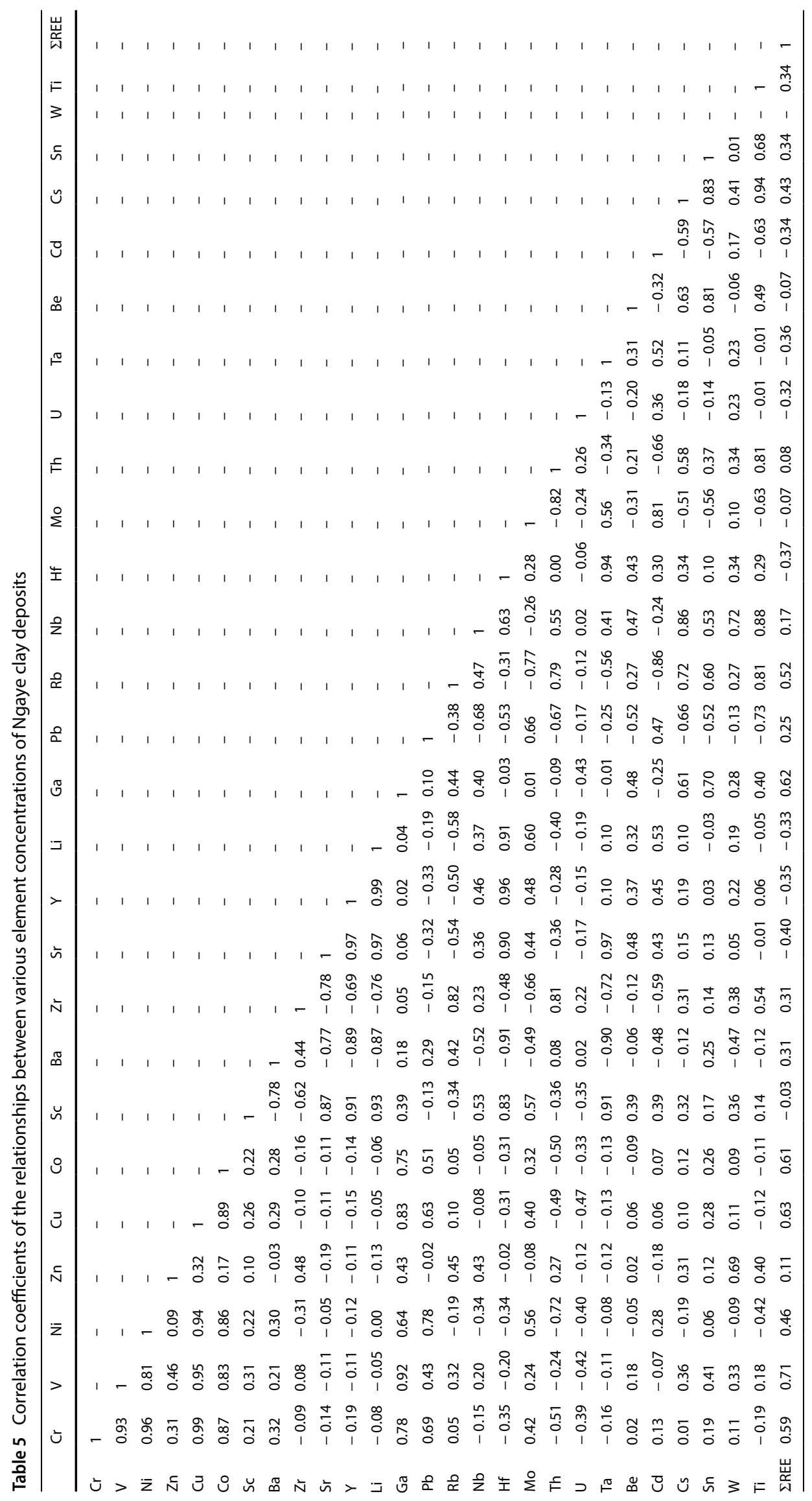


of sequence $B$ and the lowest in the bottom of sequence D (Table 4).

\subsection{Relation of REEs with trace elements}

Table 5 shows the correlation coefficients between trace elements and total REEs of the studied sequences and indicates that there is a positive correlation between $\mathrm{Cr}$, $\mathrm{V}, \mathrm{Cu}, \mathrm{Co}, \mathrm{Ga}, \mathrm{Rb}$ and $\Sigma \mathrm{REE}$ (correlation coefficients` 0.50 ). Many of these elements are transition element, suggesting that REEs of the Ngaye alluvial sediments are mainly from the terrigenous formations.

\section{Discussion}

\subsection{Origin and tectonic context}

Previous works on these alluvial sediments indicate that the materials result from gneisses, amphibolites and granites [1]. The uniform, sandy-rich textures of profiles A, B, $C$ and $D$ are believed to be related to the hydrolytic processes that affect source rocks. The diversity of lithological formations, associated with hydrolytic processes (dominant bis-aluminization and monosialitization), justify the presence of different types of clay minerals in all of the studied profile. Also, it is important to note that despite the fact that the sampled profiles are already visually very different, their present a relatively same proportion of particle size distribution and clay mineral, with the exception of the smectite which is present as a trace in the sequence $A$ and $C$. The difference in colour observed in the samples profiles may be reflected, climatic condition during deposition of these sediments. Grey to black colours in the bottom of sequences should be the consequence of humus or organic matter accumulation and dysoxic to anoxic conditions during cooler or humid period [16], [17]. Yellowishbrown to red colours observed in some sequences could be reflected the hydration of ferric oxide and extensive weathering of the parental mineral content during warm period as suggested previously by [18]. Reddish to brownish colour in the sequences can be related to favourable environmental conditions: high insolation and temperature, due to low latitude, and the lack of carbon limitation in an environment rich in carbonates and largely open to the atmosphere [19]. The redness and yellowness of sequences are chiefly caused by the contents of hematite and fullonite, and their correlations to climate are the best in humid regions in tropic and warm temperate regions.

To access the origin of the sediment, geochemistry trace of elements has been used as proxies (eg [4]). Thus, elevated values of $\mathrm{Cr}$ ('150 ppm) and $\mathrm{Ni}$ ('100 ppm) have been considerate of ultramafic sources. In this study, all the sampled profiles show relatively high $\mathrm{Cr}$ and low $\mathrm{Ni}$ contents, which indicate that Ngaye alluvial sediments do not come from ultramafic rock. REE patterns and the Eu anomaly values can be useful to the determination of the provenance of clastic sediment [2]. Felsic igneous rocks generally present negative Eu anomalies, whereas mafic igneous rocks contain little or lack of Eu anomalies. Total REE contents in sediment are closely related to the percentage of clay, and silt-sized particles such as REE are generally enriched in clay and silt fractions, but depleted in sand fraction, because of dilution by quartz and feldspar [20]. It is showed that clay minerals have a strong absorptive capacity for REEs [21, 22]. Also, in sediments, the LREE is preferentially immobilized by clay and Fe-oxyhydroxides particles while HREE tends to be maintained in solution [23], leading to a HREE fractionation which is more pronounced in fine-grained sediments. The analysed alluvial deposit samples show in the entire sampled profiles the high LREE (165-234, mean 194 ppm and low HREE (9.47-30.51; mean 15.93 values and negative Eu anomalies (1.00 in average compared to UCC rocks. Similar conclusion has been suggested for the recent sediment from lower Catumbela River in Angola [24]. In the other hand, the LREE-enriched patterns of the analysed samples compared to North American Shale (NASC) [25] may indicated a possible felsic source for the studied alluvial sediment. This may indicate that the Ngaye alluvial sediment comes from Felsic source rocks. The non-migratory elemental concentration ratios such as $\mathrm{La} / \mathrm{Sc}$, Th/Sc, Th/ $\mathrm{Co}, \mathrm{Th} / \mathrm{Cr}$ are very useful as good discriminators between mafic and felsic source rocks. These ratios of the analysed alluvial deposit samples (Tables 2-4) have been compared to those of the upper continental crust (UCC), and the similarity in the observed values suggest that the sediment from the Ngaye were derived from rocks of similar composition as UCC [3]. La, Th and Zr are more concentrated in felsic igneous rocks, whereas $\mathrm{Ni}, \mathrm{Co}, \mathrm{Sc}$ and $\mathrm{Cr}$ have high concentration in mafic rocks (Ali et al. 2014). The La/Sc and $\mathrm{Th} / \mathrm{Sc}$ ratios, therefore, are useful fingerprints of the source of sediments. The La/Sc ratios of the Ngaye alluvial sediments (1.39-5.95, average 3.70 , as well as their Th/Sc ratios $(0.08-2.58$, average 1.24 are higher than those of the UCC $(\mathrm{La} / \mathrm{Sc}=2.70 ; \mathrm{Th} / \mathrm{Sc}=0.97$, suggesting a relatively more felsic source origin for the studied sediments. The similar result has been suggested for the recent sediment in the paleo-life rich Olduvai and Laetoli basins of northern Tanzania [26]. The relatively high $\mathrm{Cr}$ contents observed in practically all analysed sample of the Ngaye alluvial sediments may suggest a contribution of mafic source in these areas or probably indicate a multi-source provenance of the studied sediments [27]. This has been confirmed by the discrimination diagram of $\mathrm{Hf}$ vs $\mathrm{La} / \mathrm{Th}$ which indicated a multi-source provenance of the sediments. These alluvial 

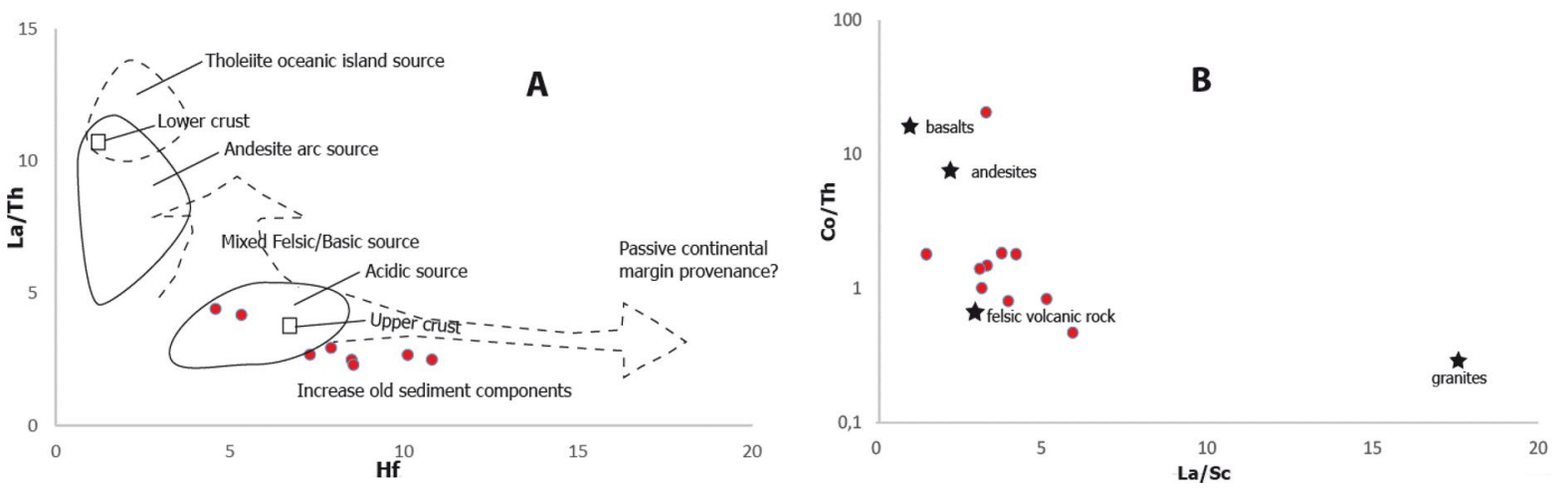

Fig. 6 Source and compositional discrimination of the Ngaye alluvial clay deposits, Mbere Djerem Basin (after Floyd and Leveridge 1987)

Fig. 7 LREE vs. La/Yb diagram of the Ngaye alluvial clay deposits, Mbere Djerem Basin ( modified from Liu et al. 2016)

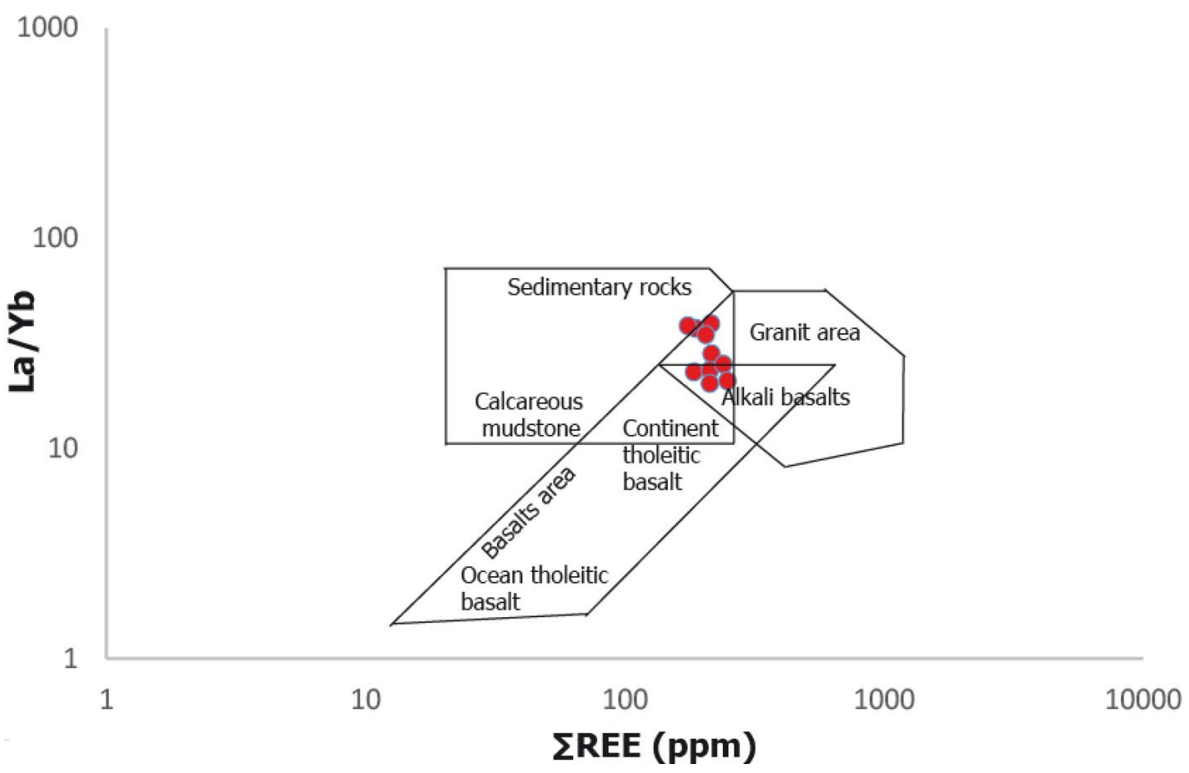

area of the Ngaye locality [28]. These may also explain the high proportion of quartz in sediment.

In addition, in order to determine the tectonic setting of the studied area, the Th-Co-Zr/10 and La-Th-Sc ternary discrimination diagram have been used [29]. The data, plotted in these diagrams, fall within the continental island arc suggesting that the tectonic setting of the Ngaye alluvial sediment was a continental island arc (Fig. 8). This tectonic setting has previously been suggested for the Rey Bouba Greenstone Belt in northern Cameroon [30].

\subsection{Depositional and paleoclimate condition interpretation}

In order to interpret depositional environment during sedimentation, $\mathrm{V} / \mathrm{Ni}, \mathrm{V} /(\mathrm{V}+\mathrm{Ni}), \mathrm{V} / \mathrm{Cr}, \mathrm{Ni} / \mathrm{Co}$ and $\mathrm{Th} / \mathrm{U}$ ratios are used as proxies to carry out depositional conditions [31]. Generally, range of ' 3.0 and $1.9-3.0$ for the $\mathrm{V} / \mathrm{Ni}$ ratio is indicative, respectively, of reducing and suboxic condition of primary uplifting of the Adamawa horst surrounding 

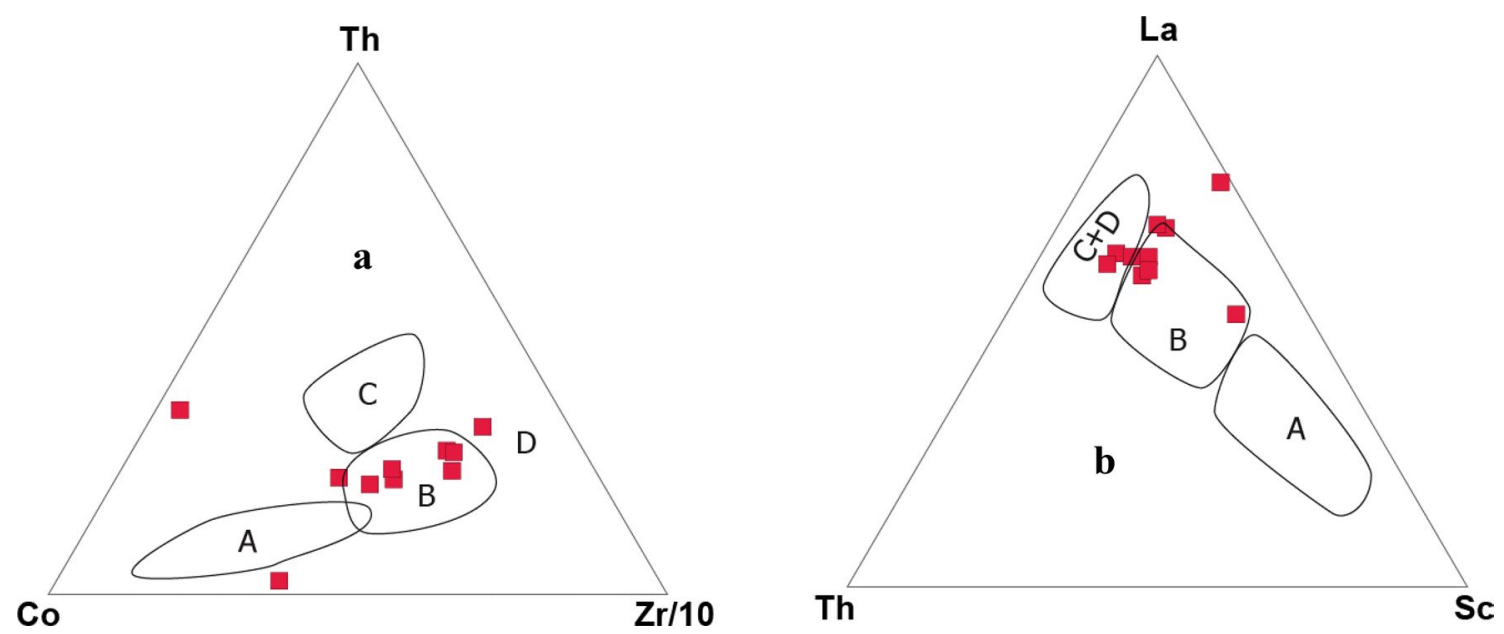

Fig. 8 Tectonic discrimination plots of $\mathbf{a} \mathrm{La}-\mathrm{Th}-\mathrm{Sc}$ and $\mathbf{b}$ Th-Co-Zr/10 for Ngaye alluvial clay deposits from the Mbere Djerem Basin (after Bhatia and Crook, 1986). $A=$ oceanic island arc; $B=$ continental island arc; $C=$ active continental margin; $D=$ passive margin

[7] as well as the value of $\mathrm{V} /(\mathrm{V}+\mathrm{Ni})$ ratio of $0.84,0.60-0.84$ and $0.40-0.60$, respectively, represent euxinic, anoxic and dysoxic conditions. Other trace elemental ratio such as $\mathrm{Th} / \mathrm{U}, \mathrm{V} / \mathrm{Cr}, \mathrm{Ni} / \mathrm{Co}$ can also be used to determine depositional condition. However, recent study indicates that Th, Co and their ratios are inappropriate as indicators for reflecting redox conditions because their concentrations may be affected by detrital sources input [8]. The ratio $\mathrm{Th} / \mathrm{U}$ can be used to indicate the weathering degree [32], as $T h$ is immobile in the superficial environment while $U$ is strongly mobile [33]. Th/U ratios of Ngaye samples are close and below Th/U ratio of UCC, indicating weak chemical weathering of the source rocks. The values of $\mathrm{V} / \mathrm{Ni}$ ratio range from 1.98-2.78 except for the sample NGA1 (1.58) and values of $\mathrm{V} /(\mathrm{V}+\mathrm{Ni})$ ratio range from $0.61-0.73$ indicating suboxic to dysoxic condition during deposition of the Ngaye alluvial sediment.

Concerning the paleoclimate interpretation, some trace element and their ratios can be used as proxies such as $\mathrm{Ga} /$ $\mathrm{Rb}$ and $\mathrm{Sr} / \mathrm{Cu}$ ratios [34], [10]. In general, the presence of the Gallium in some milieu is reflected warm and humid climate when it related with the fine-grained aluminosilicate as kaolinite. In addition, rubidium is associated with illite and implying weak chemical weathering related with dry and cold climatic conditions. Similarly, the declines $\mathrm{Ga} / \mathrm{Rb}$ ratio in sediments indicate the evolution of climate from colder to drier. Likewise, high $\mathrm{Ga} / \mathrm{Rb}$ and low $\mathrm{Sr} / \mathrm{Cu}$ ratios in sediments indicate humid and warm climate conditions [31]. A range of 1.3-5.0 for the value of $\mathrm{Sr} / \mathrm{Cu}$ ratio can indicate humid environment while the value higher than 5.0 represent arid environment [31,34].

The $\mathrm{Ga} / \mathrm{Rb}$ ratio values range from $0.19-1.47$ whereas those $\mathrm{Sr} / \mathrm{Cu}$ ratio range from $2.81-29.34$. These proxies imply that Ngaye area was characterized by humid climate condition during the depositional period of Ngaye alluvial sediments. Recent works in Adamawa plateau [10] suggest this paleoclimate hypothesis.

\section{Conclusion}

Geochemical elements of the alluvial clays deposit in the Ngaye locality, Mbere-Djerem basin, North Cameroon shows that source rocks consist of alkali basalts, granites and sedimentary rocks, as suggested by the diagram of $\mathrm{REE}$ and $\mathrm{La} / \mathrm{Yb}$. Discriminant diagrams, consisting of LaTh-Sc and Th-Co- $\mathrm{Zr} / 10$, suggest that the tectonic setting of the Ngaye area was a continental island arc. Redox proxies $(\mathrm{V} / \mathrm{Ni}, \mathrm{V} /(\mathrm{V}+\mathrm{Ni}))$ indicate that the alluvial sediments were deposited in a relatively suboxic to dysoxic condition. The concentration of climate proxies trace elements and their ratios such as $\mathrm{Sr} / \mathrm{Cu}$ and $\mathrm{Ga} / \mathrm{Rb}$ indicate that the dry and humid climate was prevailing during the depositional period.

Acknowledgements This work was partially supported by the Geoscience Laboratories (Sudbury, Canada). The authors are grateful to team manager of the Cameroon Oil Transportation Company (COTCO) for providing logistic facilities during the field work. They also express their gratitude to all the anonymous reviewers who have greatly improved the quality of this manuscript.

\section{Compliance with ethical standards}

Conflict of interest On behalf of all authors, there is no conflict of interest. 


\section{References}

1. Ndjigui P-D, Beauvais A, Fadil-Djenabou S, Ambrosi J-P (2014) Origin and evolution of Ngaye River alluvial sediments, Northern Cameroon: geochemical constraints. J Afr Earth Sci 100:164-178

2. Singh P (2009) Major, trace and REE geochemistry of the Ganga River sediments: influence of provenance and sedimentary processes. Chem Geol 266:251-264

3. Cullers RL, Basu A, Suttner LJ (1988) Geochemical signature of provenance in sand-size material in soils and stream sediments near the tobacco root batholith, Montana, U.S.A. Chem Geol 70:335-348

4. Armstrong-Altrin JS, Machain-Castillo ML, Rosales-Hoz L, Carranza-Edwards A, Sanchez-Cabeza JA, Ruíz-Fernández AC (2015) Provenance and depositional history of continental slope sediments in the Southwestern Gulf of Mexico unraveled by geochemical analysis. Cont Shelf Res 95:15-26

5. Singh P, Rajamani V (2001) REE geochemistry of recent clastic sediments from the Kaveri floodplains, southern India: implication to source area weathering and sedimentary processes. Geochim Cosmochim Acta 65:3093-3108

6. Ahmad AHM, Noufal KN, Masroor AM, Khan T (2014) Petrography and geochemistry of Jumara Dome sediments, Kachchh basin: implications for provenance, tectonic setting and weathering intensity. Chin J Geochem 33:9-23

7. Galarraga F, Llamas JF, Martinez A, Martinez M, Marquez G, Reategui $\mathrm{K}$ (2008) V/Ni ratio as a parameter in palaeoenvironmental characterization of non-mature medium-crude oils from several Latin American basins. J Petrol Sci Eng 61:9-14

8. Guoliang X, Yulin S, Shugen L, Weiduo H (2018) Trace and rare earth element (REE) characteristics of mudstones from eocene pinghu formation and oligocene huagang formation in Xihu Sag, East China Sea Basin: implications for provenance, depositional conditions and paleoclimate. Mar Pet Geol. https://doi. org/10.1016/j.marpetgeo.2018.02.019

9. Zhao JH, Jin ZJ, Jin ZK, Geng YK, Wen X, Yan CN (2016) Applying sedimentary geochemical proxies for paleoenvironment interpretation of organic-rich shale deposition in the Sichuan Basin, China. Int J Coal Geol 163:52-71

10. Nnanga A, Ngos S, Ngueutchoua G (2018) The late Pleistocene - holocene paleoclimate reconstruction in the Adamawa plateau (Central Cameroon) inferred from the geochemistry and mineralogy of the Lake Fonjak sediments. J Afr 150:28

11. Fadil-Djenabou S, Ndjigui P-D, Mbey JA (2015) Mineralogical and physicochemical charaterization of Ngaye alluvial clays (Northern Cameroon) and assessment of its suitability in ceramic production. J Asian Ceram Soc 3:50-58

12. Tchameni R, Pouclet A, Penaye J, Ganwa AA, Toteu SF (2006) Petrography and geochemistry of the Ngaoundéré Pan-African granitoids in Central North Cameroon: implications for their sources and geological setting. J Afri Earth Sci 44:511-529

13. Brabant, P., Gavaud, M., 1985. Les sols et les ressources du NordCameroun. Cartes + notice explicative ORSTOM, 285 pp.

14. Bach W, Irber W (1998) Rare earth element mobility in the oceanic lower sheeted dyke complex: evidence from geochemical data and leaching experiments. Chem Geol 151:309-326

15. Gromet LP, Dymek RF (1982) A redetermination of REE in the North American shale composite and implications for crustal models. EOS 63:467

16. Yang SL, Chen SY (1999) Soil Color: a new sensitive indicator for climatic change. Chinese Sci Bull 44(Supp. 1):282-285

17. Trichet J, Défarge C (1999) Sedimentary organic matter derived from cyanobacteria: composition, structure and propeties of kopara deposits. Bull. Inst. Oceanogr. Monaco (special issue) 19:203-208
18. Sims ZR, Nielsen GA (1986) Soil genesis, morphology, and classification: organic carbon in Montana soils as related to clay content and climate, Soil Sci. Soc Am J 50:1269-1271

19. Défarge C, Trichet J, Maurin A, Hucher M (1994) Kopara in Polynesian atolls: early stages of formation of calcareous stromatolites. Sediment Geol 89:9-23

20. Wang S, Zhang N, Chen H, Li L, Yan W (2014) The surface sediment types and their rare earth element characteristics from the continental shelf of the northern South China Sea. Cont Shelf Res 88:185-202

21. Nesbitt HW (1979) Mobility and fractionation of REE during weathering of granodiorite. Nature 279:206-210

22. Yang SY, Jung HS, Choi MS, Li CX (2002) The rare earth element compositions of the Changjiang (Yangtze) and Huanghe (Yellow) river sediments. Earth Planet Sci Lett 201:407-419

23. Caccia VG, Milero JF (2007) Distribution of yttrium and rare earths in Florida Bay sediments. Mar Chem 104:171-185

24. Manuela MMVG, Pinto MMSC, Carvalho PCS (2016) Major, trace and REE geochemistry of recent sediments from lower Catumbela River (Angola). J Afr Earth Sc 115:203-217

25. Haskin LA, Haskin MA, Frey FA, Wildman TR (1968) Relative and absolute terrestrial abundances of the rare earths. In: Ahrens $\mathrm{LH}$ (ed) Origin and distribution of the elements. Pergamon, Oxford, pp 889-912

26. Kasanzu CH, Maboko MAH, Shukrani M (2016) Reconstruction of pliocene-pleistocene sediment sources and weathering intensity in the paleo-life rich Olduvai and Laetoli basins of northern tanzania using major and trace element geochemistry and sr isotopic data. J Afr Earth Sc 123:89-98

27. Marques RM, Isabel DMI, Prudêncio RF (2011) Upper cretaceous clayey levels from western Portugal (Aveiro and Taveiro regions): clay mineral and trace-element distribution. Clays Clay Miner 59(3):315-327. https://doi.org/10.1346/CCMN.2011.0590307

28. Le Maréchal A, Vincent PM (1971) Le fossé Crétacé du SudAdamaoua (Cameroun). Cahiers d'ORSTOM, Série Géologiques $3(1): 67-83$

29. Bhatia MR (1985) Rare earth element geochemistry of Australian Paleozoic graywackes and mudrocks: provenance and tectonic control. Sed Geol 45:97-113

30. Bouyo MH, Zhao Y, Penaye J, Zhang SH, Njel UO (2015) Neoprotorozoic subduction-related metavolcanic and metasedimentary rocks from the Rey Bouba Greenstone Belt of north-central Cameroon in the Central African Fold belt: new insights into a continental arc geodynamic setting. Precambr Res 261:40-53

31. Xu QL, Liu B, Ma YS, Song XM, Wang YJ, Chen ZX (2017) Geological and geochemical characterization of lacustrine shale: a case study of the Jurassic Da'anzhai member shale in the central Sichuan Basin, southwest China. J Nat Gas Sci Eng 47:124-139

32. Meinhold G, Kostopoulos D, Reischmann T (2007) Geochemical constraints on the provenance and depositional setting of sedimentary rocks from the islands of Chios, Inousses and Psara, Aegean Sea, Greece Implications for the evolution of Palaeotethys. J Geol Soc 164(6):1145-1163

33. White WM (2013) Geochemistry. Wilwy Blackwell, NJ, p 660

34. Sarki Yandoka BM, Abdullah WH, Abubakar MB, Hakimi MH, Adegoke AK (2015) Geochemical characterisation of early cretaceous lacustrine sediments of bima formation, Yola sub-basin, Northern Benue trough, NE Nigeria: organic matter input, preservation, paleoenvironment and palaeoclimatic conditions. Mar Pet Geol 61:82-94

Publisher's Note Springer Nature remains neutral with regard to jurisdictional claims in published maps and institutional affiliations. 